\title{
PENGARUH PENERAPAN PENDEKATAN SCIENTIFIC DENGAN MODEL PEMBELAJARAN BERBASIS MASALAH TERHADAP KETERAMPILAN SOSIAL SISWA MATERI MANUSIA DAN LINGKUNGANNYA DI SEKOLAH DASAR
}

\author{
Ilmawati Fahmi Imro \\ FKIP Universitas Nusantara PGRI Kediri \\ Alamat e-mail : ilmawati@unpkediri.ac.id
}

\begin{abstract}
This research aims to describe the influence of the application scientific approach with problem based learning toward social skill of students material learning human and environment in primary school. This research using Quasi experiment with the research pretest-posttest control group designs. A subject of reseach is student IVA and IVB singkalanyar 2 prambon nganjuk. Based on the results of the study were analyzed by using SPSS 19.0 points out that there is a scientific approach to the application of the influence model of problem-based learning based on social skills students on material learning human and environment in primary school. Evidenced by $t$ count $(18,076)>t$ tabel $(2,021)$. Based on data analysis, we can conclude that the application of scientific approach problem based learning related to material learning human and environment in primary school can be used as the alternatives learning that might improve social skill students.
\end{abstract}

Keywords: Scientific approach, problem based learning, social skill student, human and environment.

\begin{abstract}
ABSTRAK
Penelitian ini bertujuan untuk mendeskripsikan pengaruh penerapan pendekatan scientific dengan model pembelajaran berbasis masalah terhadap keterampilan sosial siswa materi manusia dan lingkungannya di Sekolah Dasar. Penelitian ini menggunakan penelitian Quasi eksperimen dengan rancangan penelitian Pretestposttest control group design. Subjek penelitian kelas IVA dan IVB SDN Singkalanyar 2 Prambon Nganjuk. Berdasarkan hasil penelitian yang dianalisis dengan menggunakan SPSS 19.0 menunjukkan bahwa ada pengaruh penerapan pendekatan scientific model pembelajaran berbasis masalah terhadap keterampilan sosial siswa pada materi manusia dan lingkungannya di Sekolah Dasar dibuktikan dengan $t$ hitung $(18,076)>t$ tabel $(2,021)$. Berdasarkan analisis data, dapat disimpulkan bahwa penerapan pendekatan scientific model
\end{abstract}


pembelajaran berbasis masalah pada materi manusia dan lingkungannya di sekolah dasar dapat digunakan sebagai salah satu alternatif model pembelajaran yang dapat keterampilan sosial siswa.

Kata Kunci : Pendekatan scientific, model pembelajaran berbasis masalah, keterampilan sosial siswa, manusia dan lingkungannya.

\section{A. Pendahuluan}

Pendidikan merupakan suatu kegiatan yang universal dalam kehidupan manusia. Dalam UUD 1945 disebutkan bahwa salah satu tujuan negara Indonesia adalah mencerdaskan kehidupan bangsa, yaitu melalui pendidikan, dimana dengan pendidikan akan menghasilkan generasi yang berkualitas yang akan berperan dalam pembangunan bangsa dan negara dalam era globalisasi. Pendidikan saat ini diarahkan agar generasi penerus bangsa memiliki keterampilan yang akan menjadi modal pembangunan negara yang luar biasa. Salah satu pendidikan yang mampu meningkatkan keterampilan siswa adalah proses pembelajaran pada jenjang sekolah dasar sampai perguruan tinggi.

Pembelajaran pada setiap mata pelajaran setidaknya harus memiliki tiga ranah pembelajaran yakni kognitif, psikomotor dan afektif. Kognitif yakni tahapan berpikir yang dimiliki seseorang atau siswa dari jenjang pendidikan dasar maupun perguruan tinggi. Dalam kognitif siswa harus mampu meningkatkan pengetahuan, pemahaman, penerapan, menganalisis, mensintesis, dan mampu untuk mengevaluasi. Sedangkan psikomotor siswa harus mampu terampil dalam sebuah praktik pembelajaran. Serta afektif yakni siswa mampu memiliki perilaku yang mencerminkan sikap berakhlak mulia, percaya diri, bertanggung jawab dalam berinteraksi dengan lingkungan sosial dan alam.

Ketiga ranah tersebut harus ada dalam proses pembelajaran, yang paling dominan untuk saat ini selain kognitif yang dikedepankan adalah afektif. Dengan afektif siswa mampu menunjukkan perilaku yang mencerminkan sikap berakhlak mulia, percaya diri, bertanggung jawab dalam berinteraksi dengan lingkungan sosial dan alam diharapkan siswa mampu melibatkan 
dirinya secara efektif untuk melakukan interaksi terhadap lingkungan dan melakukan kejasama dengan orang lain guna menghadapi masalah-masalah yang ada di sekitar anak.

Berkaitan dengan hal tersebut peneliti bermaksud mengadakan observasi tentang kondisi siswa kelas IV di beberapa sekolah dasar di kecamatan Prambon kabupaten Nganjuk. Observasi dilakukan saat pembelajaran berlangsung di dalam kelas serta wawancara tak terstruktur kepada guru di luar jam pelajaran. Melalui observasi tersebut digali informasi tentang sikap siswa saat pembelajaran berlangsung.

Berdasarkan hasil observasi dapat disimpulkan bahwa pada saat pembelajaran berlangsung dengan materi manusia dan lingkungannya, ditemukan realita sosial berupa kurang tanggapnya siswa dalam menghadapi masalah-masalah yang terjadi baik itu masalah nyata ataupun yang dihadirkan oleh guru. Misalkan ketika guru menghadirkan sebuah masalah tentang kondisi lingkungan sekitar siswa, siswa masih terlihat tidak aktif untuk memberi tanggapan tentang hal tersebut. Seolah-olah mereka tidak pernah memikirkan hal itu baik tentang penyebab ataupun cara mengatasinya. Padahal salah satu kerampilan sosial yang seharusnya dimiliki siswa adalah peduli terhadap lingkungan sebagai wujud bahwa mereka tanggap dengan kondisi sekitar.

Dari hal di atas tidak sesuai dengan tujuan mata pelajaran IPS yang dikemukakan Ahmadi (2011:10) yang menyatakan bahwa IPS mengharuskan anak didik memiliki kemampuan sebagai berikut (1) Mengenal konsep-konsep yang berkaitan dengan kehidupan masyarakat dan lingkungannya, (2) memiliki kemampuan dasar untuk berpikir logis dan kritis, rasa ingin tahu, inkuiri, memecahkan masalah, dan keterampilan dalam kehidupan sosial, (3) memiliki komitmen dan kesadaran terhadap nilai-nilai sosial dan kemanusiaan, dan (4) memiliki kemampuan berkomunikasi, bekerja sama dan berkompetisi dalam masyarakat yang majemuk, ditingkat lokal, nasional dan global.

Berdasarkan pernyataan tersebut, terlihat bahwa adanya kesenjangan antara kenyataan dengan harapan yang mengharuskan siswa untuk mengenal konsep- 
konsep yang berkaitan dengan kehidupan masyarakat dan lingkungannya, kemudian, siswa harus memiliki kemampuan dasar untuk berpikir logis dan kritis, rasa ingin tahu, memecahkan masalah dan keterampilan dalam kehidupan sosial, selanjutnya memiliki komitmen dan kesadaran terhadap nilai-nilai sosial dan kemanusiaan, serta memiliki kemampuan berkomunikasi, bekerja sama dan berkompetisi dalam masyarakat yang majemuk, ditingkat lokal, nasional dan global.

Hal ini tidak terlihat dalam proses pembelajaran bahwa keterampilan sosial tentang perilaku terhadap lingkungan masih rendah. Keterampilan sosial sangat diperlukan dalam kehidupan seharihari siswa. Pentingnya keterampilan sosial bagi siswa yakni siswa dapat menunjukkan tingkah laku sosial individu dalam mengenal dan memperlakukan lingkungan hidupnya, menunjukkan tingkah laku sosial individu mengenal dan mengadakan hubungan dengan sesama individu lain (dengan teman sebaya atau guru), siswa dapat menunjukkan tingkah laku sosial individu terhadap dirinya sendiri secara positif, serta siswa dapat menunjukkan perilaku atau respon positif terhadap sejumlah tugas akademis.

Salah satu solusi untuk menciptakan pembelajaran yang meningkatkan keterampilan dalam kehidupan sosial bagi siswa yakni menggunakan model pembelajaran berbasis masalah yaitu karena model pembelajaran berbasis masalah adalah model yang menjadikan situasi atau masalah autentik menjadi titik tolak dalam pembelajaran untuk memahami konsep, prinsip dan mengembangkan keterampilan memecahkan masalah. Selain itu melibatkan siswa dalam proses pembelajaran yang aktif yakni siswa membangun, menemukan, menstransformasikan, dan memperluas pengetahuan mereka sendiri dengan berkolaborasi. Jadi siswa mencari tahu masalah yang ingin diselesaikan dengan bekerjasama dengan teman kelompoknya. Sehingga diharapkan dengan menggunakan model pembelajaran berbasis masalah siswa dapat meningkatkan keterampilan sosial.

Berdasarkan permasalahan dan penyebab permasalahannya yang telah diuraikan tersebut, salah satu 
alternatif untuk meningkatkan keterampilan sosial siswa, penulis mengajukan penelitian yang berjudul "Pengaruh penerapan pendekatan scientific dengan model pembelajaran berbasis masalah terhadap keterampilan sosial siswa materi manusia dan lingkungannya di Sekolah Dasar".

\section{B. Landasan Teori}

\section{Metode Penelitian}

Jenis penelitian ini menggunakan penelitian Quasi eksperimen. Subjek penelitian ini adalah siswa kelas IVA dan IVB SDN Singkalanyar 2 Prambon Nganjuk. Rancangan yang digunakan dalam penelitian ini adalah Pretest-Postest Control Group Design dengan kelompok kontrol dan kelompok eksperimen (Sugiyono, 2011:76). Variabel bebas dalam penelitian ini adalah pendekatan scientific model pembelajaran berbasis masalah. Variabel terikat dalam penelitian ini adalah keterampilan sosial.

Data dalam penelitian ini adalah Observasi yakni menggunakan intrumen lembar observasi keterampilan sosial dengan berdasarkan indikator keterampilan sosial yakni (1) perilakunya terhadap lingkungan yaitu peduli lingkungan, (2) perilakunya terhadap teman sebaya atau guru (interpersonal) dengan indikatornya bekerjasama dengan teman, kepedulian, dan menghargai orang lain, perilakunya yang berhubungan dengan diri sendiri dengan indikator perilaku bertanggung jawab, sikap positif terhadap diri sendiri, serta (4) perilakunya yang berhubungan dengan tugas dengan indikator mengajukan dan menjawab pertanyaan, perilaku mengikuti pelajaran, diskusi kelas, menyelesaikan tugas-tugas, membantu orang lain, aktivitas kelompok, kerja mandiri, perilaku berdasarkan tugas, tampil sebelum yang lain dan kualitas kerja. Analisis data menggunakan uji-t.

\section{Hasil dan Pembahasan}

Hasil keterampilan sosial siswa baik dalam kelas eksperimen maupun kelas kontrol dapat dilihat pada Tabel 1 sebagai berikut.

Tabel 1 Rata-rata Keterampilan Sosial Siswa

\begin{tabular}{|c|c|c|c|}
\hline Kelompok & $\begin{array}{c}\text { Rata- } \\
\text { rata }\end{array}$ & $\begin{array}{c}\text { Rata- } \\
\text { rata }\end{array}$ & $\begin{array}{c}\text { Kenai- } \\
\text { Kan } \\
\end{array}$ \\
& $\begin{array}{c}\text { Pre- } \\
\text { test }\end{array}$ & $\begin{array}{c}\text { Post- } \\
\text { test }\end{array}$ & $(\%)$ \\
\hline
\end{tabular}




\begin{tabular}{|c|c|c|c|}
\hline $\begin{array}{c}\text { Eksperim- } \\
\text { en }\end{array}$ & 21,21 & 46,58 & 25,37 \\
\hline Kontrol & 23,17 & 34,83 & 11,66 \\
\hline Beda (\%) & 1,96 & 11,75 & \\
\hline
\end{tabular}

(Sumber: data diolah)

Setelah dilakukan uji prasyarat analisis data yaitu uji normalitas dan uji homogenitas untuk menjawab hipotesis yang diajukan, maka uji analisis yang dipergunakan dalam penelitian ini adalah independent sample $t$ test.

Dari hasil perhitungan SPSS pada Tabel 4.21, nilai $t$ hitung keterampilan sosial siswa pada saat pre-test sebesar-1,377 (df.40). Dari hasil perhitungan tersebut, diperoleh nilai thitung $(-1,377)<$ tabel $(2,021)$, maka Ho diterima dan $\mathrm{Ha}$ ditolak. Jadi keputusannya pada pre-test keterampilan sosial siswa "Tidak ada perbedaan keterampilan sosial siswa yang mengikuti pembelajaran dengan menerapkan pendekatan scientific dengan model pembelajaran berbasis masalah dengan pembelajaran ceramah pada materi manusia dan lingkungannya di Sekolah Dasar.

\section{E. Kesimpulan}

Ada perbedaan keterampilan sosial siswa yang mengikuti pembelajaran dengan pendekatan scientific model pembelajaran berbasis masalah dengan pembelajaran ceramah, hal ini dibuktikan dengan nilai thitung $(18,076)$ $>$ tabel (2,021). Sehingga dapat dikatakan bahwa ada pengaruh penerapan pendekatan scientific model pembelajaran berbasis masalah terhadap keterampilan sosial siswa materi manusia dan lingkungannya di Sekolah Dasar.

\section{DAFTAR PUSTAKA}

Ahmadi, Khoiru lif. (2011). Mengembangkan pembelajaran IPS terpadu. Jakarta: PT. Prestasi putrakaraya.

Arends, Richard. (2008). Learning to teach. Yogyakarta: Pustaka belajar

Arikunto, Suharsimi. (2012). Dasardasar evaluasi pendidikan. Jakarta: Bumi Aksara

Aqib, Zainal. (2009). Penelitian Tindakan Kelas untuk guru SD, SLB dan TK. Bandung: Yrama widya.

Joyce, B.R., Weil, M., and Showers, B. (1992). Models Of Teaching. United states of America: York production services.

Mardiana, Anita. (2012). Penerapan Model Kooperatif Tipe TGT Untuk Meningkatkan Keterampilan Sosial Siswa SDN Banaran Kertosono. Surabaya: Universitas Negeri Surabaya. Mulyasa. (2013). Pengembangan Dan Implementasi Kurikulum 
2013. Bandung: PT Remaja Rosdakarya.

Mustaji \& Sugiarso. (2005). Pembelajaran berbasis konstruktivistik penerapan pembelajaran berbasis masalah. Surabaya : Unesa university press.

Ngalimun. (2014). Strategi dan model pembelajaran. Yogyakarta: Aswaja Pressindo.

Nur, Mohamad. (2011). Model pembelajaran berdasarkan masalah. Surabaya:Pusat sains dan matematika sekolah unesa

Riyanto, Yatim. (2007). Metodologi penelitian pendidikan kualitatif dan kuantitatif. Surabaya: Unesa university press

Riyanto, Yatim. (2010). Paradigma baru pembelajaran sebagai referensi bagi pendidik dalam implementasi pembelajaran yang efektif dan berkualitas. Jakarta: Kencana

Sagala, Syaiful.(2006). konsep dan makna pembelajaran untuk membantu memecahkan problematika belajar dan mengajar. Bandung: Alfabeta

Sapriya. (2009). Pendidikan IPS Konsep dan Pembelajaran. Bandung: PT. Remaja Rosdakarya

Skeel, D.J. (1995). Elementary Social Studies: Challenge For Tommorow's World. New York: Harcourt Brace College Publishers

Slameto. (1996). Teknik evaluasi pendidikan. Jakarta: Raja Grafindo Persada
Sudrajat, Ahmad. (2013).Diklat guru: Analisis materi ajarkonsep pendekatan scientific jenjang SD/SMP/SMA. Jakarta: Kemendikbud

Sugiyono. (2011). Metode penelitian kuantitatif, kualitatif dan $R \& D$. Bandung: Alfabeta.

Sugiyono._(2012). Statistika untuk penelitian.Bandung: Alfabeta.

Suhanadji \& Waspodo. (2003). Pendidikan IPS. Surabaya: percetakan insan cendekia

Sunarto dan Hartono, Agung. (2006). Perkembangan Peserta Didik. Jakarta:Rineka Cipta

Tilaar, dkk. (2011). Pedagogik kritis. Jakarta: Rineka Cipta

Trianto. (2011). Model-Model Pembelajaran Inovatif Berorientasi Konstruktivistik Konsep, Landasan TeoritisPraktis Dan Implementasinya. Jakarta: prestasi pustaka.

Winataputra, Udin dkk. (2007). Materi dan pembelajaran IPS SD. Jakarta: Universitas terbuka

Yamin, Martinis. (2013). Strategi \& metode dalam model pembelajaran.Jakarta: GP Press Group. 